\title{
Adult Education and Academic Libraries
}

\author{
Abstract \\ Purpose - The purpose of this review is to offer practicing academic librarians an overview of \\ adult education theories as a way to more deeply understand and further foster adult learning in \\ academic libraries.
}

Design/methodology approach - This article is a literature review.

Findings - This review introduces academic librarians to a range of specific adult education learning theories, it offers examples of academic library users engaging in these types of adult learning, it considers how academic libraries can further foster adult learning, and it identifies major characteristics of adult learners.

Originality/value - This literature review offers a summative overview of adult education in a way that has not appeared in the library literature to date, along with explicit connections between adult education theories and academic library practices.

Keywords: adult education; education theories; academic libraries; higher education

\section{Introduction}

The field of adult education has much to offer to the study and practice of academic librarianship. It can offer theories that can help explain, illuminate, and amplify interactions with adult learners in library spaces. The intent of this article is to offer practicing academic librarians some useful background information on the theories and understandings of adult education that can easily be applied to academic library settings. Its hope is to then make academic library spaces more explicitly supportive of adult learners and conducive to adult education. 


\section{Literature Review}

The literature of academic librarianship does include information on adult education, but it is generally either not the focal point of the investigation, or it is not explicitly examined by name in theory or in practice. One rare recent exception appears to be Ludovico's 2017 article that looks at the ACRL Framework for Information Literacy from the perspective of adult students who fall outside the 18-22 year old boundaries of traditionally aged college students. In this article, she plants the important question of "How can we, as librarians who work more and more with adult students, incorporate the best of adult education theory into our information literacy instruction?" (Ludovico, 2017, p. 250). Her answer to this question lies in seeing information literacy as an informative transaction, rather than a transformative one, for students who are not part of the 18-22 year old cohort on campus.

This current article, in contrast, starts with theories of adult education first and then considers their application to all areas of library practice, including but not limited to information literacy. A further difference is that this article considers all learners past the age of 18 to be adult learners, in accordance with adult education theorists such as Brookfield who advocates that, “...college teachers can and should...treat their students as the adults they actually are, or the adults they are becoming” (Brookfield, 2015, p. 23). The age of 18 to reflect adulthood was chosen because this is a common legal understanding. This definition of an adult as someone over 18 is also offered here to be inclusive. In other words, any academic library user, not just older adults over the age of 18 who are returning to college, are considered to be adults here. To be similarly inclusive, "college" is also used here in its broadest sense to reflect any institution of higher education at the tertiary level. No distinction is offered here between "college" and 
"university" for that reason, although the use of these terms is understandably different in different national contexts.

While the literature of academic librarianship does not contain an overabundance of explicit articles on adult education, its presence can certainly still be felt. For example, in a recent review of library literature concerning lifelong learning, the author states that one of its most commonly associated terms is "adult learning" (Mahoney, 2017, p. 543). That lifelong learning is an important concept in current academic literature is reinforced by its emergence as a core library value (Elmborg, 2016). In addition, library anxiety, distance education, and outreach have all been considered from the perspective of older adult students (Tieman and Black, 2017; Veal, 2002). In an interesting twist, academic librarians have also been seen as needing to engage in adult education themselves for professional development purposes (Attebury, 2015).

Academic library literature from the 1980s until around 2000 seems to mark the first sustained considerations of adult learners in libraries as distinct from other learners. In 1986, for example, andragogy, an adult education theory described below, is introduced as "a new concept for academic librarians" (Sheridan, 1986, p. 156). "International adult learners" then appeared in the literature (Chatto, 2000; Liestman, 2001), as did work on the needs and characteristics of adult library users (Ingram, 2000) and reflections on reference services for adult learners (Ghaphery, 2000). Considerations of adult learning in libraries continue to appear in the academic library literature, even if they do not unequivocally exhibit the phrase "adult education" (Elmborg, 2010).

Library literature on public libraries can offer further insights to academic librarians as well on the topic of adult education. Public library programs and services aimed at adult learners invoke the role of the public library as an agent for community building (Scott, 2011), as a place 
to build social capital (Varheim, 2010), and as a site for public policy to come to life (McCook \& Barber, 2002).

And of course the literature on adult education itself is a wealth of information. Often, when libraries are mentioned in this set of literature, they point to public libraries as the site for adult education. For example, adult educators see public libraries as a place for adult learners to experience responsibility (Notar, 2008), as an avenue for non-native speakers of English to experience language success (Pete, 2016), and as an intersection between $21^{\text {st }}$ century learning and adult education (Ward, 2007). These views of the public library by adult educators might apply to academic libraries as well.

In addition, there are further aspects of the literature on adult education that can also potentially inform all librarians. This literature includes explanations of general learning philosophies (Wang, 2012) such as behaviorism (that emphasizes modelling and mimicry), cognitivism (that emphasizes mental processes), and humanism (that emphasizes a positive, holistic approach). It can also offer librarians overviews on how adult education links theory and practice (Merriam and Bierema, 2014). And it can highlight particular perspectives of adult education that could be recognized in academic libraries, such as the presence of barriers (Flynn et al., 2011), the role of learner self-efficacy (Shi, 2016), online instruction considerations for adult learners (Arghode and Brieger, 2017), and the need to see adult learning as consisting of many layers (Boeren, 2017).

What this survey of the literature shows is that the literature of academic librarianship can support further understandings of adult education. To that end, the next section of this article will now provide further information on the meanings of adult education. 


\section{The Meaning of Adult Education}

Adult education has been understood in various ways since Malcolm Knowles began addressing what it meant to teach adults rather than children in his seminal 1970 book, The Modern Practice of Adult Education (Knowles, 1970). His work stressed the differences that adults bring to learning in comparison with children in areas such as the need to know, the learners' selfconcepts, the roles of the learners' experiences, readiness to learn, orientation to learning, and motivation (Knowles et al., 2014, pp. 43-47).

Adult education is also sometimes understood solely as the purview of workforce development or the provision of vocational skills to learners who may not be traditionally recognized as part of the landscape of higher education. This view of adult education now seems to be changing to more broadly to include the education of all adults in many different settings. These settings and populations now comprise, for example, adult learning in:

- worker training for adults who never continued their education past high school

- language instruction like English as a second language (ESL) training to new immigrants and refugees in a community

- higher education courses and programs offered to prison populations

- educational opportunities offered to senior citizens and retirees

- educational workshops and programs for recreational and leisure learners

- the training and continuing education of working professionals

- all forms of tertiary education 
Current work by researchers further emphasizes learning as the most important way to comprehend adult education:

Adult learning is at the heart of our practice as adult educators. Whether we are offering training on new equipment at the workplace, designing continuing professional education for accountants or nurses, enrolling adults in a college course, or teaching adults English, our practice is enhanced by knowing as much as we can about who our learners are as well as how they learn. (Merriam and Bierema, 2015, p. 11).

Practicing academic librarians can benefit from this advice as well. What seems most important to consider is that learners in library environments in higher education are adult learners in their own right. An understanding of adult education can only benefit academic librarians working with them in these settings.

\section{Adult Education Theories and Examples of Adult Learners}

The literature of librarianship has been enriched by knowledge of theories from other fields. Conteh-Morgan, for example, offered practicing academic librarians some very useful information on theories of second language learning (2002). As a reason for making use of theories that normally fall outside the bounds of librarianship, she states that, "Awareness of theories of second language learning and approaches to teaching is vital if librarians are to provide more meaningful instruction to LEP [limited English proficiency] students" (p. 191). In much the same way, this article now attempts to provide similar theories for librarians from adult education for the same purpose of enhancing the practice of librarianship. 
The understanding and practice of adult education relies on more than one theory. The main theories of adult education look at the continuing educational development of individuals over the age of 18 in ways that differentiate them from children. The more predominant theories of adult education are briefly summarized below, followed by examples of adult learners who could represent a lived version of the theory in practice.

\section{Andragogy}

This theory promotes the idea that adults learn differently from children. Adults have different psychological and cognitive facilities than do children, and they have more choices in how to engage in education. Furthermore, the life experiences of adults often inform their choices. Autonomy can also be seen as a feature of andragogy, in that adults usually can operate far more independently than children can as regards when, where, and how to engage in learning.

Examples of adult learners exhibiting andragogy could be online distance education learners who are going back to school for further formal education in a higher education setting, as well as other specialized adult learners such as divinity school students who have chosen ministry as a second career path.

\section{Self-Directed Learning}

The ability to engage in learning under one's own self-direction is not necessarily limited to adults, but it may be easier to understand and facilitate with adults. Adults tend to generally have more life responsibilities as well in terms of dealing with finances, time restrictions, and child care duties and so on, all of which add to the need to be able to manage their own learning. 
Examples of self-directed adult learners could include adults who have been home tending children now returning to higher education as a way back into the workforce, and other adult students returning to a college for a second degree for any other personal reason.

\section{Lifelong Learning}

As noted in the literature review, this theory of learning is often a catch-all phrase. Its appearance in adult education focusses mainly on motivational reasons for adults to engage in continuing education. As such, it is often used with recreational and leisure learners who engage in ongoing learning opportunities often for the sheer pleasure of it or for the enhancement of their own personal hobbies and interests.

Examples of lifelong learners could be retired individuals engaging in continuing education choices at institutions of higher education, as well as other adult learners taking advantage of reduced college fees to audit courses with younger students working on their first degrees. They could also include local adults pursuing genealogy research in the special collections and archives of college libraries.

\section{Transformational Learning}

This theory refers to the "aha" moment of discovery, when an adult suddenly sees something in a different way from what past experience dictates. This again is not unavailable to children, but its presence in adult learning has often been used as a way to explain adult reactions to new understandings of knowledge.

Examples of adult learners engaging in transformational learning experiences are not bounded to any setting of higher education, but could include senior citizens engaging in medical research 
in a college setting, as well as any other adult encountering new information through a library resource that results in an enhanced view of any aspect of their own being in the universe of knowledge.

\section{Third Age Learning}

This theory relates directly to the learning experienced by adults in the last "third" of their lives, following childhood and then young adulthood. It most typically is applied to retirees and senior citizens who have left the workforce and are now entering the phase of their lives not dominated by children or employment.

Examples of adult learners engaged in third age learning could include any physically older adult engaged in research well beyond the years of their formal schooling, as well as geriatric patients making use of college library resources to improve their own physical well-being or mental acuities.

\section{Critical Adult Education}

This most recent view of adult education advocates for the social betterment of adult learners through political means. Its emphasis seems geared more towards the group, not solely on the improvement of an individual adult learner, and its overall purpose is social justice or progressive reform.

Examples of adult learners taking part in critical adult education could be community social reformers looking to make college libraries safe spaces for minority or disadvantaged youth, as well as adult reformers working to promote ideals like inclusivity or indigenization on college campuses. 
All of the theories and examples mentioned above may reflect the core of adult education and its practioners, but they do not comprise the full spectrum of what adult education fully includes. Not mentioned here, but also worth being aware of, for example, are other theories of education that lend themselves to adult applications as well. These include theories such as social constructivism (co-creating knowledge from experience), multiple intelligences (learning in different ways), and experiential learning (learning from doing).

In addition, examples of practioners who embody or illustrate these various manifestations of what adult education can be are also limitless. And neither are any of these theories or examples completely discrete and inseparable from each other. Overlap is quite possible, as for example with critical adult education adherents also able to be engaging in andragogy as well as lifelong learning at the same time. None of these categories are therefore exclusive.

What is key to remember is that adult education theories seek to distinguish adult learning from the learning done by children, and that its practioners engage in its various forms supported by this same outlook.

\section{Academic Library Applications of Adult Learning Theories}

These adult education theories support adult learners as learners in their own right and as distinct from children in terms of their particular needs, choices, motivations, situations, experiences, and preferences. These theories can also apply both to the traditional college age grouping of 18-22 year olds, a diminishing demographic on many North American campuses, as well as to older adults coming back to college or entering college for the first time. Called "non-traditional students" in the United States and "mature students" in Canada, this group of adult learners can be distinct from the traditional 18-22 year olds, but they are both forms of adult learners. As 
such, both types of adult learners can benefit from being given choices about their learning, having their situational factors taken into account (work schedules, family needs, etc.), and being respectfully treated as responsible adult members of the academic community.

Furthermore, adult learning theories can offer important insights that could be applied to all learners in general, regardless of age or level of education. The most important lesson that can be drawn from adult learning theories is that all learners are individuals with their own particular and unique characteristics, preferences, and circumstances. Libraries should aim for an inclusive approach to learning support and service delivery that recognizes this, and attempt to include choice and flexibility whenever possible that underscores this recognition.

This section will consider how academic library resources, services and spaces can be offered and enhanced to better serve adult learners.

\section{Library Resources}

Library resources represent the substance of library collections, whether they are in print or online format. These resources exist to support the academic needs of all learners as they take part in college classes and participate in research learning opportunities.

Ways to enhance adult learning through the provision of resources could include consciously offering adult students choices in how and when to access and use library resources to fit their own schedules. This can commonly be done now through making resources available online, so that an adult learner can access them any time of the day or night, depending on their own personal schedule. Print sources can also serve adult learners as well, however, if they prefer to use material in hard copy. In addition, access to print materials through browsing continues to be a preferred searching format for some users as well. 
Past experiences of adult learners can potentially influence their library use of resources as well. For example, an older learner who found solace in using print collections in an academic library space in the past may seek out a similar experience now.

\section{Library Services}

Library services can include one-on-one assistance at service desks or through individual research consultations with librarians, as well as library instruction through in-person classes and through online tutorials and other learning resources.

\section{One-on-One Assistance}

Some adult learners may prefer face-to-face meetings with librarians to discuss their research needs, while others may prefer to have this type of contact online. Even for online users, personal preferences might determine if an adult learner uses email for asynchronous contact with a particular librarian, or prefers a quicker immediate response through a synchronous chat service regardless of who is answering the question. All of these preferences are legitimate choices that adult learners ought to be supported in making in or through an academic library. Accommodating choices like these is a hallmark of adult education.

\section{Instruction}

Academic librarians delivering instruction to adult students often work both in the physical realm of offering in-person instruction sessions as well as online in the creation and delivery of library tutorials and other learning objects. Both types of instruction can support adult learners through offering choices and accounting for common barriers. For choices in a physical classroom, adult 
students could be supported by allowing for different types of learning modalities to be incorporated, perhaps some individual work, some small group work, and some time for reflection. These choices could also be accommodated online through different segments of tutorials or ways to interact with learning objects (reading, writing, multiple choice, videos, etc.).

Barriers to adult learners could also be taking into consideration in both settings. In inperson classes, accommodations could be made to offer workshops at various times of the day to fit different people's schedules. Online, adult learners could potentially work through an online tutorial at any time of the day or night. Perhaps allowing enough time over the course of a semester could also offering various completion dates as well.

\section{Library Spaces}

Current academic library spaces can now encompass both new collaborative spaces (such as Makerspaces and other technology rich places in a library, and group study areas) as well as older physical books stacks and individual seating areas. Adult learner preferences for studying individually in a quiet area can be a present motivation based on prior experience. So maintaining such areas could support this choice of some adult learners, while others may feel perfectly comfortable in some of the newer collaborative spaces. Accommodating both preferences in the form of study space choices could certainly support this group of library users.

And any potential barriers to adult learners' use and understanding of technology could be acknowledged as well in academic library spaces by offering technology training or guides to the use of particular tools that may not necessarily be as familiar to older learners as to younger learners. 


\section{Further Fostering Adult Education in Academic Libraries}

Adult education can be further fostered in an academic library setting when librarians strive to keep in mind the basic tenets of adult learners in terms of choices, motivations, situational barriers, and prior lived experiences.

\section{Choices}

Adult learners may have many preferences in terms of how to use academic libraries. They could prefer individual, self-directed uses of libraries which could be further fostered by libraries offering guides to "do it yourself" projects or online learning tutorials that can be done individually. For adult learners who prefer group learning experiences, workshops on how to use particular resources could be offered. For access preferences, both in-person and online workshops could be developed. For format preferences, library materials could be acquired both in print and online material formats.

\section{Motivations}

Adult learners may engage in learning for the sake of learning, or may be driven solely by the need to earn a certain grade for a course or a degree program. Academic librarians should be aware of both types of motivation in library use. For grade earners, academic library support such as providing extended study hours during finals week can be important, as can mounting online links to needed course reserves and channels to administrative units such as the registrar's office from the library web site. For those adult learners engaged in learning for personal satisfaction, an academic library's provision of comfortable reading spaces, good lighting, and quiet physical study spaces may satisfy some of their preferences. 


\section{Situational Barriers}

Adult learners in academic libraries can also carry with them many situational barriers to successful study such as time constraints, fiscal responsibilities, and many other life responsibilities such as child care. Academic libraries can better support these library users by keeping these situational barriers in mind, and by offering potential ways to accommodate for them. Perhaps extended loan periods, capped financial fees for overdue items, and offering information on local community help agencies could be considered for adult learners in academic library settings.

\section{Prior Life Experiences}

Adult learners in academic libraries bring with them prior lived experiences that mark their adult status. For those learners who have already been exposed to higher education, this might mean mental comparisons with other academic libraries that they have used in the past. For adult learners new to higher education, it could mean past experiences with schooling and education in general, and it most likely includes both positive and negative associations with those earlier experiences. It is important for academic librarians to keep these perspectives in mind when working with adult learners in their midst, who may be new to a particular library experience, but who are not new to educational learning experiences in general.

\section{Conclusion}

Adult education can inform academic librarianship. It offers theories of how adults learn that can be supported in library settings in higher education. These theories can help librarians 
consider how best to offer adult learners such support. Andragogy, for example, can help librarians understand that adults function at a higher cognitive level than children, so that they are more readily capable of using higher level thinking skills in library searching. Self-directed learning can help librarians understand that some adult learners would rather figure things out on their own than necessarily be given step-by-step instructions for every library procedure. Lifelong learning can help librarians understand that some adults are engaging in library use for their own personal pleasure. Transformational learning can help librarians understand that academic libraries can also serve as a place to ignite "aha" moments. Third age learning can help librarians understand that adult learning can extend to the end of a person's life cycle. And critical adult education can help librarians understand that some adults engage in learning for the sake of progressive reform and social justice.

These theories of adult education that provide academic librarians with different reasons and ways of learning all comprise common tenets that should also be recognized. The sheer amount of choices that adult learners might want to make could help expand library support to them in considerable ways, such as options for types of resources, instructional avenues, and learning spaces. The motivations of adult learners, the potential barriers they might face, and their prior life experiences can also all have an impact on how and why they are engaging in learning. Academic librarian understanding of these tenets can add to the richness of academic library use by adult learners. For example, if librarians know that adult learners are motivated to learn in different ways for different reasons, they could try to accommodate some of these different ways, whether that means offering individual and group study spaces, or print and online materials. If academic librarians recognize situational barriers sometimes faced by adult learners, these too might also be accommodated, such as providing forgiveness on loans or access to community 
health information for this group of learners. And prior life experiences in regards to schooling in the past, whether the association is positive or negative, might also be kept in mind by academic librarians working with adult learners so as to give them a current positive experience.

It is hoped that the background information in this article on adult education theories and understandings can offer academic librarians a useful perspective from which to consider their work with all learners in their libraries. If knowledge is power, then academic librarians stand to gain both when applying information about adult education to academic librarianship. 


\section{References}

Arghode, V. and Brieger, E. W. (2017), “Adult learning theories: Implications for online instruction", European Journal of Training and Development, Vol. 41 No. 7, pp. 593-609.

Attebury, R. I. (2015), “Adult education concepts in library professional development activities", New Library World Vol 116 No. 5/6, pp. 302-315.

Boeren, E. (2017), “Understanding adult lifelong learning participation as a layered Problem", Studies in Continuing Education, Vol. 39 No. 2, pp. 161-175.

Brookfield, S. D. (2015), The Skillful Teacher: On Technique, Trust, and Responsiveness in the Classroom, John Wiley \& Sons, San Francisco, CA.

Chattoo, C. D. (2000), "Reference services: Meeting the needs of international adult Learners", The Reference Librarian Vol. 33 No. 69/70, pp. 349-362.

Conteh-Morgan, M. (2002), “Connecting the dots: Limited English proficiency, second language learning theories, and information literacy instruction", The Journal of Academic Librarianship, Vol. 28 No. 4, pp. 191-196.

Elmborg, J. (2016), “Tending the garden of learning: Lifelong learning as core library Value”, Library Trends, Vol. 64 No. 3, pp. 533-556.

Elmborg, J. (2010), "Literacies, narratives, and adult learning in libraries”, New Directions for Adult \& Continuing Education, Vol. 127, pp. 67-76.

Flynn, S., Brown, J., Johnson, A. and Rodger, S. (2011), "Barriers to education for the marginalized adult learner", Alberta Journal of Educational Research, Vol. 57 No. 1, pp. 43-58.

Ghaphery, J. S. (2000), “Adult learning theory and reference services: Consonances and Potentials", The Reference Librarian, Vol. 33 No. 69/70, pp. 151-158. 
Ingram, D. S. (2000), “The andragogical librarian”, The Reference Librarian, Vol. 33 No. 69/70, pp. 141-150.

Knowles, M. S. (1970), The Modern Practice of Adult Education; Andragogy versus Pedagogy, Association Press, New York, NY.

Knowles, M. S., Holton, E. F. and Swanson, R. A. (2015), The Adult Learner:

The Definitive Classic in Adult Education and Human Resource Development, Routledge, London, UK.

Liestman, D. (2001), "Reference services and the international adult learner", The Reference Librarian Vol. 33 No. 69/70, pp. 363-378.

Ludovico, C. (May 2017), "Seeing the world through adult eyes: The ACRL framework and continuing education students", College \& Research Libraries News, Vol. 76 No. 5, pp. 250254.

Mahoney, M. H. (2017), “An academic librarian's search for meaning: A survey of lifelong learning in library literature", The Journal of Academic Librarianship, Vol. 43 No. 6, pp. 540-547.

McCook, K. de la Pena and Barber, P. (2002), "Public policy as a factor influencing adult lifelong learning, adult literacy and public libraries", Reference \& User Services Quarterly, Vol. 42 No. 1, pp. 66-75.

Merriam, S. B. and Bierema, L. L. (2014), Adult Learning: Linking Theory and Practice, Jossey-Bass, San Francisco, CA.

Notar, T. A. (2008), “Teaching responsibility through example”, Adult Basic Education \& Literacy Journal, Vol. 2 No. 3, pp. 179-181.

Pete, J. K. (2016), “A library's role in the success of adult English learners”, MPAEA 
Journal of Adult Education, Vol. 45 No. 1, pp. 1-8.

Scott, R. (2011), “The role of public libraries in community building", Public Library Quarterly, Vol. 30 No. 3, pp. 191-227.

Sheridan, J. (1986), “Andragogy: A new concept for academic librarians”, Research Strategies, Vol. 4, pp. 156-167.

Shi, L. (2016), "Empirical study on learners' self-efficacy in ESL/EFL context", College Student Journal, Vol. 50 No. 3, pp. 454-465.

Tieman, A. L. and Black, M. E. (2017), "Exploration of library outreach to nontraditional Students", Reference \& User Services Quarterly, Vol. 56 No. 3, pp. 198-205.

Varheim, A. (2010), “Gracious space: Library programming strategies towards immigrants as tools in the creation of social capital", Library \& Information Science Research, Vol. 33 No. 1, pp. 12-18.

Veal, R. (2002), "The relationship between library anxiety and off-campus adult learners", The Journal of Library Administration, Vol. 37 No. 3/4, pp. 529-536.

Wang, V. C. X. (2012), “Understanding and promoting learning theories”, International Forum of Teaching and Studies, Vol. 8 No. 2, pp. 5-11.

Ward, C. (2007), "Libraries as 21-st century learning places", Language Arts, Vol. 84 No. 3, pp. $269-272$. 